\title{
FOREIGN POLICY ALIGNMENT OF THE WESTERN BALKAN COUNTRIES WITH THE EU'S RUSSIA POLICY SINCE THE ANNEXATION OF CRIMEA
}

\section{УЗГОДЖЕННЯ ЗОВНІШНЬОЇ ПОЛІТИКИ КРАЇН ЗАХІДНИХ БАЛКАН ІЗ ПОЛІТИКОЮ ЄС ЩОДО РОСІї ПІСЛЯ АНЕКСІї КРИМУ}

\author{
Hleba O.I., \\ Senior Academic Assistant in the European Interdisciplinary Studies Department \\ College of Europe (Natolin Campus), \\ PhD Student in the International Politics Department
} Uzhhorod National University

The article evaluates the foreign policy alignment of the Western Balkan (WB) countries with the Common Foreign and Security Policy (CFSP) of the European Union (EU) under Chapter 31 of the acquis communautaire within the accession process. The EU's policy towards Russia since the latter's annexation of Crimea is chosen as a case study due to some WB countries' close ties with Russia, which resulted in the situation whereby they have been confronted with an onerous dilemma of compromising their far-reaching relations with Russia for the compliance with EU accession conditionality in the area of foreign policy.

The aim of the present article is to assess to what extent the Western Balkan countries have aligned their foreign policy with the EU's Russia policy since the annexation of Crimea. The alignment is analysed through the endorsement of relevant EU declarations, the imposition of sanctions against Russia and the votes in the United Nations General Assembly on pertinent resolutions.

The study demonstrates that while Montenegro and Albania have fully aligned their foreign policy with the EU's policy towards Russia, including the imposition of sanctions, other Western Balkan countries did not introduce sanctions and aligned with some EU declarations (North Macedonia and Bosnia and Herzegovina) or none (Serbia). As far as the five resolutions that have been adopted by the UN General Assembly are concerned, Montenegro, Albania and North Macedonia endorsed all of them, Bosnia and Herzegovina mostly abstained and Serbia voted against four. The research also reveals that Serbia's non-alignment is explained by its strategic partnership with Russia, which is based on common religion, intensive military contacts, and mutually beneficial political cooperation, especially on the sensitive issue of the recognition of Kosovo's independence by the international community.

Key words: Western Balkans, EU, CFSP, foreign policy alignment, Russia, sanctions, Crimea, Ukraine.

У статті досліджується узгодження зовнішньої політики країн Західних Балкан із спільною зовнішньою та безпековою політикою (СЗБП) Європейського Союзу (ЄС) відповідно до глави 31 acquis communautaire у рамках процесу вступу в ЄС. Політику ЄС щодо Росії після анексії Криму останньою обрано для кейс-стаді з огляду на тісні зв'язки деяких західно-балканських країн з Росією, у результаті чого вони опинились перед складною дилемою щодо того, чи жертвувати далекосяжними відносинами з Росією заради виконання умов щодо вступу в ЄС у сфрері зовнішньої політики.

Метою статті є оцінка ступеня узгодження зовнішньої політики країн Західних Балкан з політикою ЄС відносно Росії після анексії Криму. Узгодження зовнішньої політики проаналізовано через дослідження підтримки відповідних заяв ЄС, запровадження санкцій проти Росії, а також голосування у Генеральній Асамблеї ООН щодо відповідних резолюцій.

Дослідження показує, що в той час як Чорногорія та Албанія повністю узгодили свою зовнішню політику з політикою ЄС щодо Росії, включаючи запровадження санкцій, інші західні балканські країни не ввели санкцій та підтримали лише деякі заяви (Північна Македонія та Боснія і Герцеговина) або жодну (Сербія). Що стосується п'яти резолюцій, ухвалених Генеральною Асамблеєю ООН, то Чорногорія, Албанія та Північна Македонія проголосували за всі, Боснія і Герцеговина здебільшого утрималась, а Сербія проголосувала проти чотирьох. Дослідження також доводить, що неузгодження Сербії можна пояснити ії стратегічним партнерством з Росією, яке базується на спільній релігії, інтенсивних військових контактах, а також взаємовигідній політичній співпраці, особливо щодо чутливого питання визнання незалежності Косова міжнародною спільнотою.

Ключові слова: Західні Балкани, ЄС, СЗБП, узгодження зовнішньої політики, Росія, санкції, Крим, Україна.

Research problem. The Western Balkan countries, being (potential) candidates, have to meet the Copenhagen criteria, including conditions linked to membership obligations divided into 35 chapters of the acquis communautaire, in order to join the EU in accordance with Article 49 of the Treaty on European Union (TEU). Chapter 31 of the acquis, entitled 'Foreign, security and defence policy', provides for the applicant countries' progressive alignment of foreign policy with CFSP, including the introduction of restric- tive measures, e.g. sanctions. While in the past this chapter did not pose problems to applicant countries, the Western Balkans may have a different experience as many international actors, including Russia, China, Turkey, and the Gulf States, find the region geopolitically important and compete for leverage therein.

The annexation of Crimea by Russia in 2014 and its subsequent aggression in Eastern Ukraine, as defined in Article 3 of the UN General Assembly Resolution 3314 (XXIX), has made Russia a frequent point on 
the CFSP agenda of the European Union. The EU has repeatedly condemned Russia's actions, urged Russia to abide by international law and restore Ukraine's territorial integrity within its internationally recognised borders, and introduced sanctions. As part of the accession process, the European Union has systematically invited the Western Balkan countries to align themselves with its policy towards Russia, which retains close ties with some of these countries. This development has placed a number of the Western Balkan countries in a dilemma of pursuing EU membership and by extension condemning Russia's actions against Ukraine, including the introduction of sanctions, or maintaining strategic relations with Russia.

Literature review and the research gap the article addresses. The present research lies at the junction of European studies and foreign policy analysis as it looks into the foreign policy alignment of the Western Balkans with the EU CFSP within the accession process, which is profoundly linked to the Western Balkans' foreign policy priorities and their relations with other external actors. As most scholarly publications in this area focus on a number of the Western Balkan countries rather than the entire region $[1 ; 2]$ or look into other external actors' policy towards the region, e.g. Russia [3; 4], this article adopts a comparative, region-wide approach with the purpose of identifying and explaining the countries' distinct trajectories of the foreign policy alignment with the EU CFSP if such exist. Another contribution is a joint analysis of three foreign policy alignment mechanisms - declarations, voting in multilateral organisations and sanctions against third countries.

Objectives of the article. The aims of the article are as follows:

- describe the state of play of the EU's enlargement towards the Western Balkans;

- evaluate the political significance of foreign policy alignment within the EU accession process;

- analyse the foreign policy alignment of the Western Balkan countries with EU declarations over 2012-2019 and assess the impact of Russia's annexation of Crimea and aggression in Eastern Ukraine thereon;

- evaluate the Western Balkans' alignment of voting with the EU member states on the UN General Assembly resolutions concerning the situation in Ukraine since 2014;

- study the reasoning behind the Western Balkan countries' (non-) introduction of sanctions against Russia.

Main text of the article. In the aftermath of the violent dissolution of Yugoslavia in the 1990s, the Western Balkan countries embarked on an ambitious path towards European integration via the Stabilisation and Association Process. They were given a clear membership perspective first at the European Council in Santa Maria da Feira in June 2000, which held that "all the countries concerned are potential candidates for EU membership" [5; emphasis added], and further on at the Thessaloniki EU-Western Balkans Summit in June 2003, when the EU solemnly stated that "the future of the Balkans is within the European Union" [6, p. 1; emphasis added].

As of October 2019, the (former) Western Balkan countries have accomplished distinct progress in terms of their movement towards EU membership. Slovenia joined the EU already in 2004 and Croatia became the EU's youngest member state in 2013. As the EU's definition of the Western Balkans as a region is politically-driven, both countries ceased to be considered part of the region once their respective accession agreements entered into force.

Montenegro and Serbia have been engaged in the accession negotiations since 2012 and 2014, with 32 and 16 chapters of the acquis opened respectively. North Macedonia has been a candidate country since 2005, but due to the 'name dispute' with Greece the decision to open membership negotiations was blocked several times. In addition, North Macedonia recently concluded a bilateral agreement with Greece concerning the name of the country (Prespa Agreement) in order to lift the Greek veto on its accession to the EU and NATO. Yet the leaders of France, Denmark and the Netherlands were opposed to opening membership negotiations with North Macedonia and Albania at the most recent EU summit on 17-18 October 2019, which prevented the adoption of the decision requiring unanimity among EU member states. Albania has had the candidate status since 2014 and is now in the same situation as North Macedonia.

The two remaining Western Balkan countries, namely Bosnia and Herzegovina and Kosovo («Освіта і підготовка 2010 - Успіх Лісабонської стратегії залежить від термінових реформ»), are potential candidates as they have not been granted the candidate status. Bosnia and Herzegovina applied for EU membership in 2016 and the European Commission issued its opinion on the country's application in 2019, concluding that the country does not meet the accession criteria and emphasising a set of key priorities where Bosnia and Herzegovina needs to demonstrate progress to receive the candidate status. Kosovo has not yet submitted its application for EU membership. The Stabilisation and Association Agreement between the EU and Kosovo came into effect in 2016. Due to Kosovo's non-recognition by Spain, Greece, Romania, Slovakia, and Cyprus, EU member states are not parties to the agreement and, as a result, it only covers the areas where the EU has exclusive competence under Article 3 of the Treaty on the Functioning of the European Union.

\section{Foreign policy alignment as an integral part} of the accession process

The EU accession process is based on the criteria adopted by the Copenhagen European Council in 
1993 and further strengthened by the Madrid European Council in 1995 as well as additional conditionality specific for a country or region in question. These criteria are grouped in three categories [7]:

1) political - stability of institutions guaranteeing democracy, the rule of law, human rights and respect for and protection of minorities;

2) economic - a functioning market economy and the ability to cope with competitive pressure and market forces within the EU;

3) membership-related - administrative and institutional capacity to effectively implement the acquis and ability to take on the obligations of membership.

Conditions under the third category are divided into 35 chapters of the acquis. Foreign policy alignment constitutes an integral part of Chapter 31, namely "Foreign, security and defence policy". This chapter stipulates that "applicant countries are required to progressively align with EU statements, and to apply sanctions and restrictive measures when and where required" [8]. The aims of this provision are twofold. First, applicant countries are supposed to articulate that they share the principles and objectives of the EU's external action set out in Article 21 TEU. Second, they need to exemplify this declaration in the pre-accession period by concrete steps of alignment with CFSP.

The EU's thorough approach to applicant countries' foreign policy within the accession process has roots in the intergovernmental nature of CFSP whereby it is subject to specific rules and procedures, the adoption of legislative acts is excluded, the Court of Justice of the EU has almost no jurisdiction, and the European Council and the Council of the EU act mostly unanimously (Article $24 \mathrm{TEU}$ ). The required unanimity among member states implies that the final decision is usually the lowest common denominator all member states can accept and that one member state's divergent position suffices to halt a decision. Therefore, a hypothetical accession of a country that for one reason or another is not ready to uphold the EU's values, principles and objectives on the international scene could render CFSP utterly incapacitated and undermine the EU's ambition of "speaking with one voice".

The European Commission scrupulously monitors the alignment of the foreign policy of applicant Western Balkan countries, i.e. all WB countries but Kosovo, with CFSP and incorporates the collected information into its regular country reports. The importance the EU attaches to foreign policy alignment within the enlargement process can be seen, for instance, in the recent EU documents relating to the Western Balkans. The Sofia declaration of the EU-Western Balkans summit (May 2018) reads:

"The EU welcomes the contribution of the Western Balkans partners to its Common Foreign and Security Policy (CFSP) in all its aspects and expects a progressive deepening of cooperation in this area, especially an enhanced level of alignment, notably on issues where major common interests are at stake" $[9$, p. 3 ; emphasis added].

The most illustrative example can be found in the Commission's most recent Communication on EU Enlargement Policy (May 2019), which states:

"Speeding up alignment with the EU Common Foreign and Security Policy, including on restrictive measures, is an important part of the enlargement process and an important element to confirm that the countries fully share the principles, values and goals that the Union seeks to promote in its neighbourhood and beyond" [10, p. 2; emphasis added].

2. Foreign policy alignment of the Western Balkans with the EU CFSP

The foreign policy alignment of the Western Balkan countries with the EU CFSP can be studied by various means depending upon the subject under consideration. Attempting to produce a comprehensive outlook, this research looks into three ways an applicant country can align its foreign policy with CFSP, namely alignment with EU declarations, including the ones on Russia over Ukraine, alignment with the EU's voting in the UN General Assembly on resolutions concerning the situation in Ukraine, and the introduction of sanctions against Russia.

\subsection{Western Balkans' alignment with EU decla-} rations in 2012-2019

2012 has been chosen as a starting point because of two considerations. First, the first Western Balkan country, out of the six, commenced accession negotiations with the EU (Montenegro). Second, since the annexation of Crimea by Russia took place in 2014, an analysis of foreign policy alignment during two pre-annexation years is of paramount importance to the assessment of the impact of Russia's arrival onto the CFSP agenda on the Western Balkans' alignment with CFSP.

Over the period of 2012 to 2019, Montenegro, Serbia, North Macedonia, and Albania have been invited to align with a total of 383 EU declarations. Bosnia and Herzegovina has been requested to align with 354. As Kosovo is not an applicant country and $5 \mathrm{EU}$ member states do not recognize its independence, the EU has not invited Kosovo to align itself with foreign policy statements [11].

The average rate of the foreign policy alignment of the Western Balkans with CFSP over the last 7 years, as reported by the European Commission, ranges from $63 \%$ for Bosnia and Herzegovina and $67 \%$ for Serbia, to $84 \%$ in the case of North Macedonia and $100 \%$ for Montenegro and Albania [11].

It is important to verify if the yearly alignment rate has been stable across the years, if there have been some rising or falling tendencies or if there have been significant peaks or troughs, possibly triggered by developments in world politics that were reflected on 


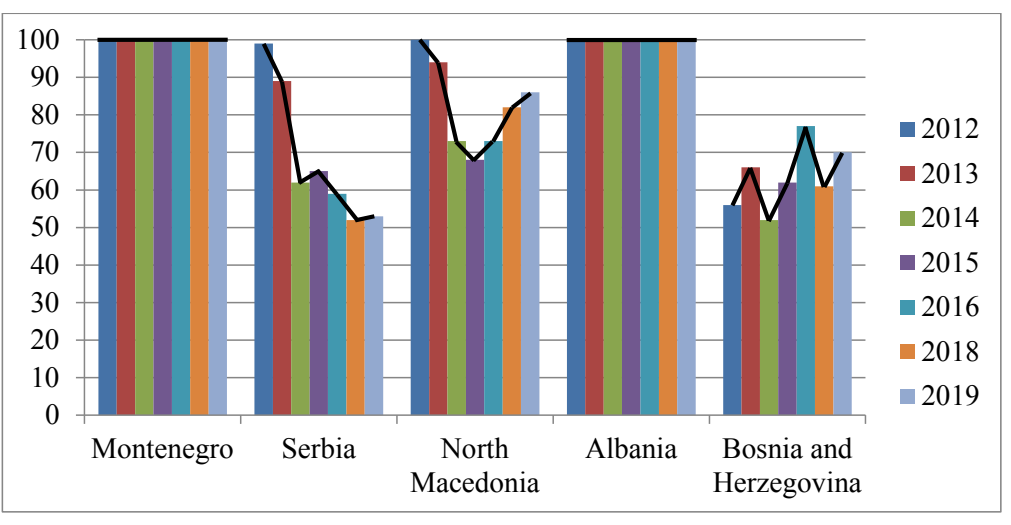

Figure 1 The Western Balkans' foreign policy alignment with EU CFSP declarations in 2012-2019' (percentage)

Source: Own analysis on the basis of the European Commission reports [11]

the CFSP agenda. The EU's ambition is to ensure that the applicant countries progressively align themselves with CFSP and eventually reach $100 \%$ alignment rate in the pre-accession period [12].

The annual alignment rate analysis (figure 1) identifies four patterns of alignment across the region.

First, Montenegro and Albania have consistently aligned with CFSP in all instances and are the 'frontrunners', for what they have been praised by the European Commission on various occasions. Second, there is a regressive alignment in the case of Serbia, which reached $99 \%$ alignment rate in 2012 , but then dipped to $62 \%$ in 2014 (27\% decrease compared to 2013 ) and even a trough of $52 \%$ last year. The situation has slightly improved in 2019 (53\%), but given the overall steep downward trajectory over 2012-2019 it remains to be seen if the rate continues to increase. Third, the case of North Macedonia shows a 4-year period of regressive alignment from $100 \%$ in 2012 to $68 \%$ in 2015 , with a $21 \%$ decrease from 2013 to 2014 alone. From 2016 on, one can observe a 3-year progressive increase of alignment from $68 \%$ in 2015 to $86 \%$ in 2019. Forth, Bosnia and Herzegovina's graph has a zigzag shape, with a maximum of three consecutive years of movement in either of the ways, an increase from $52 \%$ in 2014 to $77 \%$ in 2016 , but then there was a $16 \%$ decrease in 2018 , followed by a $9 \%$ improvement in 2019. In general, the alignment rate seems to be on the rise in the period of 2012-2019.

2.2. Impact of Russia's annexation of Crimea and aggression in Eastern Ukraine on the Western Balkans'alignment with $E \boldsymbol{U}$ declarations

As the numbers suggest, Serbia and North Macedonia experienced a drastic decrease of the alignment rate in 2014 compared to the previous year. Taking

\footnotetext{
${ }^{1}$ The bars in the figure refer to the reporting period of the European Commission's report published in a given year. For years 2012-2016, the reporting period starts in October of the preceding year and finishes with September of the year when the report was issued. In the case of 2018 and 2019, the reporting periods are October 2016 - February 2018, and March 2018 - March 2019 respectively.
}

into account that 2014 is the year when Russia annexed Crimea and began its aggression in Eastern Ukraine and that the EU has since then produced numerous documents calling upon Russia to abide by international law and restore Ukraine's territorial integrity, it is worth analysing if the EU has invited the Western Balkans to align with the aforesaid declarations, and if so, whether this novelty negatively influenced the WB countries' alignment with CFSP.

Table 1 presents aggregate numbers of all declarations (column 2) and Russia-related ones (column 4) the EU has invited the Western Balkans to align with over the last five years and a half. It further displays the non-alignment rate with respect to all EU declarations (column 1) and Russia-related ones (column 3) that the Western Balkans has been invited to endorse. Column 5 shows the degree to which non-alignment with Russia-related EU declarations matters for the overall non-alignment rate in the case of all EU declarations.

Over the period of 2014 - June 2019, the European Commission has invited the Western Balkans to align with 245 declarations in total, 47 of which relating to Russia over its actions against Ukraine. Montenegro and Albania have demonstrated 100\% alignment with declarations of both types. Serbia has not aligned with 103 of 245 declarations (42\% non-alignment rate). In particular, it has not aligned itself with a single Russia-related EU declaration, ignoring all of the EU's 47 invitations. This implies that Russia-related declarations account for $46 \%$ of all EU declarations Serbia has failed to uphold. North Macedonia's alignment record is somewhat better. It has not aligned itself with only $50 \mathrm{EU}$ declarations (20\% non-alignment rate). As for Russia-related statements, it has not found it possible to endorse 38 out of 47 of them ( $81 \%$ non-alignment rate). Therefore, the weight of Russia-related declarations in relation to the number of all EU statements North Macedonia has not supported over the last five and a half years is the highest in the region and constitutes $76 \%$. Bosnia and Herzegovina, by contrast, has not endorsed $89 \mathrm{EU}$ declarations (36 non-alignment rate). It has aligned itself with only 4 out of 47 Russia-related declarations ( $91 \%$ non-alignment rate). As a consequence, $48 \%$ of EU declarations Bosnia and Herzegovina has not endorsed over 2014 - June 2019 were linked to Russia.

The above statistics reveals that the arrival of Russia as a regular point on the CFSP agenda has made it more difficult for the Western Balkans to align with the EU CFSP and, therefore, has had a significant negative impact on the region's alignment, except Montenegro and Albania. Returning to the noticeable decrease of alignment in 2014, Russia-related state- 
ments accounted for $59 \%, 82 \%$ and $53 \%$ of the overall non-alignment of Serbia, North Macedonia and Bosnia and Herzegovina respectively. The case of North Macedonia is revealing as the same indicator reached $88 \%$ in 2018 and even $100 \%$ one year before [2].

2.3. Voting of the Western Balkans in the UN General Assembly on the resolutions concerning the situation in Ukraine since 2014

Another important aspect of applicant countries' convergence with CFSP is the alignment with the EU's common position in multilateral organisations such as the United Nations. The EU encourages applicant and other partner countries to support its initiatives and align with its statements in the UN General Assembly, where it enjoys an "enhanced observer status' since 2011 and is entitled to make interventions.

Over the last five years the UN General Assembly has adopted five resolutions which deal with the situation in Ukraine. The first resolution, entitled "Territorial integrity of Ukraine" was adopted on 27 March 2014 (A/RES/68/262), whereby the General Assembly "affirmed its commitment to the sovereignty, political independence, unit and territorial integrity of Ukraine within its internationally recognized borders" and stated that the so-called referendum held in Crimea had no validity [13]. All EU member states, Albania, Montenegro and North Macedonia voted in favour of the resolution, whereas the diplomats of Serbia and Bosnia and Herzegovina walked out of the General Assembly Hall and did not vote [14].

The General Assembly returned to the subject during three consecutive sessions in 2016-2018 and adopted three resolutions under almost identical title, namely "Situation of human rights in the Autonomous Republic of Crimea and the city of Sevastopol, Ukraine" (A/RES/71/205, A/RES/72/190, $\mathrm{A} / \mathrm{RES} / 73 / 263)$. In these resolutions, the General Assembly condemned "the temporary occupation of part of the territory of Ukraine - the Autonomous Republic of Crimea and the city of Sevastopol [...] by the Russian Federation", reaffirmed "the non-recognition of its annexation" and urged the Russian
Federation to "uphold all of its obligations under applicable international law as an occupying Power" [13]. All EU member states, Albania, Montenegro and North Macedonia backed the resolution, Bosnia and Herzegovina abstained, and Serbia voted against the resolution [14].

As a reaction to Russia's capture of three vessels of Ukraine's naval forces with 24 servicemen in the Black near the Kerch Strait at the end of November 2018, the UN General Assembly adopted the resolution "Problem of the militarization of the Autonomous Republic of Crimea and the city of Sevastopol, Ukraine, as well as parts of the Black Sea and the Sea of Azov" (A/RES/73/194) in December 2018. The General Assembly expressed its utmost concern about the "unjustified use of force by the Russian Federation against Ukraine", called upon the "Russian Federation to release the vessels and their crews and equipment unconditionally and without delay" and urged the "Russian Federation, as the occupying Power, to withdraw its military forces from Crimea and to end its temporary occupation of Ukraine's territory without delay" [13]. Again, EU member states unanimously endorsed the resolution together with Albania, Montenegro and North Macedonia. Bosnia and Herzegovina did not vote and Serbia was opposed to the resolution, hence it voted against [14].

This short analysis encapsulates that Montenegro, Albania and North Macedonia have consistently endorsed the UN General Assembly regarding the situation in Ukraine, which the EU championed, whereas Serbia voted against all but on resolutions and Bosnia and Herzegovina either abstained or did not vote at all.

3. The Western Balkans' alignment with the EU sanctions against Russia through the lens of the external incentives model

As far as the introduction of sanctions against Russia is concerned, the Western Balkan countries, having all been requested to impose them, split into two camps: Montenegro and Albania complied with the EU sanctions policy whereas Serbia, North Mac-

The impact of the EU's Russia policy on the Western Balkans' alignment with EU CFSP Table 1 declarations in 2014 - June 2019

\begin{tabular}{|l|c|c|c|c|c|}
\hline Country & $\begin{array}{c}\text { Number of } \\
\text { EU declarations } \\
\text { not aligned with } \\
\text { (of 245) }\end{array}$ & $\begin{array}{c}\text { Non-alignment } \\
\text { rate } \\
\text { (all EU } \\
\text { declarations) }\end{array}$ & $\begin{array}{c}\text { Number of } \\
\text { Russia-related } \\
\text { EU declarations } \\
\text { not aligned with } \\
\text { (of 47) }\end{array}$ & $\begin{array}{c}\text { Non-alignment } \\
\text { rate } \\
\text { (Russia-related } \\
\text { EU declarations) }\end{array}$ & $\begin{array}{c}\text { Ratio } \\
\text { of Russia-related } \\
\text { non-alignment }\end{array}$ \\
\hline Montenegro & 0 & $0 \%$ & 0 & $0 \%$ & Not applicable \\
\hline Serbia & 103 & $42 \%$ & 47 & $100 \%$ & $46 \%$ \\
\hline North Macedonia & 50 & $20 \%$ & 38 & $81 \%$ & $76 \%$ \\
\hline Albania & 0 & $0 \%$ & 0 & $0 \%$ & Not applicable \\
\hline $\begin{array}{l}\text { Bosnia and } \\
\text { Herzegovina }\end{array}$ & 89 & $36 \%$ & 43 & $91 \%$ & $48 \%$ \\
\hline
\end{tabular}

Source: Own analysis on the basis of the ISAC reports [2] 
edonia and Bosnia and Herzegovina did not. Besides, Kosovo introduced sanctions against Russia since its convergence with CFSP-related restrictive measures is one of the priorities of the political dialogue between Kosovo and the EU under Article 11 of the Stabilisation and Association Agreement [15].

In order to find out the reason of this split among the countries in region, we need to uncover the meaning of the statements that were made by the Western Balkan political leaders on the sanctions against Russia. The external incentives model (EIM), developed by Frank Schimmelfennig and Ulrich Sedelmeier, can serve as a theoretical basis for such interpretation as it helps to understand the reasoning behind candidate countries' rational choice to comply with EU conditionality or not. This puzzle lies at the core of the present research, as the target of the EU sanctions, i.e. Russia, is also a strong player in the Western Balkans with its own agenda and implicit negative conditionality, which necessarily impacts the Western Balkans' cost-benefit analysis [16, p. 3].

The EIM is built on the presumption that a country, eager to maximise its benefits and minimise its losses, is incentivised to comply with EU conditionality through a reward that it is granted once necessary conditions are fulfilled. In line with this model, conditionality is effective if (a) the reward is tangible and/ or material, big and close in time; (b) conditions are clearly stated; (c) the promise to pay a reward is credible; (d) domestic adoption costs are low. What follows is the description of these four factors in the case of foreign policy alignment [16, pp. 3-4]. Kosovo is not taken into consideration as it is not subject to the EU conditionality in this area.

The reward for the alignment with CFSP is the eventual membership in the European Union, which is tangible, material and a big according to the EIM classification. As for the question of how distant timewise rewarding is, as has been described at the beginning of the article, each Western Balkan country is in a different situation, which correlates with its progress on the EU path. Based on the EIM assumption that compliance is stronger when rewarding is closer, Montenegro and Serbia must be more incentivised to comply with the EU conditionality than North Macedonia and Albania, and much more than Bosnia and Herzegovina.

The conditions under Chapter 31 of the acquis in the part of progressive foreign policy alignment are clearly set. As shown in the previous sections, the European Commission regularly scrutinises each country's progress, provides guidelines for improvement and underlines the relevance and salience of this area.

The credibility of the promise of EU membership to the Western Balkans is unclear. Since the Thessaloniki summit in 2003 only Croatia became an EU member in 2013 (Slovenia had signed the Accession Agreement with the EU in March 2003, i.e. before the membership perspective was extended to the Balkans). Even though the European Commission and the European Parliament have continuously supported a merit-based EU's enlargement towards the Western Balkans, there is a long-standing sentiment of enlargement fatigue among the population in some EU member states whose leaders sporadically raise concerns about the Union's absorption capacity, necessity to focus on intra-Union affairs, etc. These voices of dissent send mixed messages to the Western Balkan capitals, especially taking into account that enlargement-related voting in the EU requires unanimity among EU member states.

Domestic adoption costs of alignment with CFSP are higher compared to the acquis chapters dealing with exclusively domestic issues. This is caused by the fact that foreign policy alignment involves not only the EU and the applicant country, but also third countries that are the target of the EU's statements and restrictive measures. The circle of veto players is equally broader and can be divided into two categories: internal (citizens, local businesses, etc.) and external (third countries). The critical factor that determines veto players' motivation to oppose an applicant country's alignment with the EU's policy regarding a third country is the state of relations between the two countries. The closer they are politically, economically, culturally, and the more the applicant country is dependent on the targeted country in one way or another, the costlier its alignment would be. The Western Balkan countries' relations with Russia range from tense relationship to strategic partnership, which predetermines the costs of their alignment with the EU's policy towards Russia.

As North Macedonia and Albania have not opened accession negotiations and Bosnia and Herzegovina has not been granted a candidate status, these countries may regard EU membership as less credible and, therefore, not find it necessary to comply with costly foreign policy conditionality (except Albania, which has demonstrated full alignment with CFSP) in contrast to Montenegro and Serbia, which are both negotiating EU accession. How can the external incentives model explain Montenegro's alignment and Serbia's non-alignment with the EU's Russia policy?

In terms of the credibility of EU membership perspective, Montenegro had been conducting accession negotiations already since 2012. Furthermore, when Russia annexed Crimea in February 2014 Montenegro was hoping to open Chapter 31, which was opened in June the same year. As a consequence, Montenegro had an interest in demonstrating how seriously it treated its foreign-policy-related commitments within the accession process. Besides, its domestic adoption costs were relatively low. First, Russia was not and still is not among Montenegro's main trading partners as its share in the volumes of Montenegro's export $(1.1 \%)$ and import $(0.55 \%)$ are incomparable to the 
EU (47.8\% of Montenegro's trade). Second, Montenegro was preparing to NATO membership after obtaining the Membership Action Plan in 2009, to which Russia was strongly opposed, and the relations between the two countries were tense [17].

When asked about the decision to impose sanctions on Russia, Montenegrin Prime Minister Milo Đukanović said that it was not an "anti-Russia policy" and that it was in harmony with Montenegro's key foreign policy goals, namely EU and NATO integration, which is regarded as "synonym for peace, stability, the rule of law, economic and overall development based on common European values" [18].

In the case of Serbia, credibility of the reward was somewhat weaker as Serbia de facto opened membership negotiations in January 2014, i.e. one month before the annexation of Crimea. Moreover, foreign policy conditionality was not on the agenda as screening of Chapter 31 was foreseen for July - October 2014. The screening report on this chapter is still pending approval by the EU, which leaves Chapter 31 at the most initial stage of all chapters without opening benchmarks Serbia has not opened yet. As for domestic adoption costs, they would have been enormous. This is how Serbian foreign minister Ivica Dačić reasoned Serbia's non-alignment with the EU's sanctions regime on Russia: "Had it not been for Russian support, we would not have been able to defend our national interests and territorial integrity. For its part, Serbia has reciprocated by not aligning itself with the sanctions against Russia and its people, nor will it do so in the future" [19; emphasis added]. Primary concern of Serbia would have been losing Russia as a strategic partner with a permanent seat on the UN Security, which had been and still is methodically blocking Kosovo's UN membership bid. As normalisation of relations with Kosovo is part of EU accession conditionality (Chapter 35) Serbia has to comply with, depriving itself of a powerful ally (Russia) would have been a "political suicide" [19], as Ivica Dačić put it. Close military collaboration (Serbia is an observer in Russia-led Collective Security Treaty Organisation), cooperation in the energy sector (Gazprom is the majority shareholder of the Serbian main oil and gas company) and brotherly bonds between the two predominantly Orthodox nations are but a few areas that would have been jeop- ardised as well [20]. As for trade, Russia accounted for only up to 7\% of Serbia's export and import in 2014, which would not have severely hit Serbian economy if Russia had introduced counter-measures following Serbia's sanctions [17].

Conclusions. 16 years after the Thessaloniki EU-Western Balkans Summit, where the Western Balkans was promised future EU membership, the countries show different progress on the EU integration. The same applies to the WB countries' alignment of foreign policy with the EU CFSP, including its policy towards Russia over the annexation of Crimea and actions against Ukraine. Montenegro and Albania fully complied with Chapter 31 conditionality, i.e. endorsed all EU declarations, voted for all Ukraine-related resolutions in the UN General Assembly and imposed sanctions on Russia. North Macedonia accomplished a lower level of general foreign policy alignment, ignored a prevailing number of Russia-related EU declarations, backed all relevant UN General Assembly resolutions and refrained from the introduction of sanctions against Russia. Serbia and Bosnia and Herzegovina aligned themselves with even fewer EU declarations, rejected almost all Russia-related EU declarations, did not vote in favour of the UN General Assembly resolutions in question and did not join the EU in imposing sanctions on Russia. Kosovo, which is not recognised by five EU member states, does not face EU conditionality in this field, but it nevertheless introduced sanctions against Russia as its commitment to converge with CFSP restrictive measures is reflected in its SAA with the EU.

The external incentives model helps to identify two factors which are crucial for a country's alignment with CFSP, namely credibility of the reward and domestic adoption costs. For instance, Montenegro complied because the credibility of EU membership was relatively high and its adoption costs were low due to already deteriorating relations with Russia. The case of Serbia showed that the country's strategic partnership with Russia, including the policy of Kosovo's non-recognition, constituted high adoption costs and the EU's condition of normalisation of relations between Serbia and Kosovo rendered EU membership perspective less credible. Both factors contributed to Serbia's non-alignment with the EU CFSP.

\section{REFERENCES:}

1. Artem Patalakh. Emotions and Identity as Foreign Policy Determinants: Serbian Approach to Relations with Russia. Chinese Political Science Review. December 2018, Volume 3, Issue 4, pp. 495-528.

2. International and Security Affairs Centre. URL: https://www.isac-fund.org/en/library/policy-analyses-and-policy-studies (consulted on: 25.06.2019):

a) Analiza usaglašavanja Srbije sa spoljnopolitičkim deklaracijama, stavovima i merama Evropske unije tokom 2014. godine;

b) Analiza usaglašavanja Srbije sa spoljnopolitičkim deklaracijama i merama Evropske unije tokom 2015. godine;

c) An analysis of Serbia's compliance with EU foreign policy declarations and measures in 2016;

d) An analysis of Serbia's alignment with the European Union's foreign policy declarations and measures in 2017;

e) An analysis of Serbia's alignment with the European Union's foreign policy declarations and measures in 2018; 
f) An analysis of Serbia's alignment with the European Union's foreign policy declarations and measures in 2019: Semi-annual Review.

3. Dimitar Bechev. Rival Power. Russia in Southeast Europe. Yale University Press. 2017. 319 p.

4. Stanislav Secrieru. Russia in the Western Balkans. Tactical wins, strategic setbacks. European Union Institute for Security Studies Brief No. 8. 2 July 2019. URL: https://www.iss.europa.eu/content/russia-western-balkans (consulted on: 20.07.2019).

5. Santa Maria da Feira European Council. Conclusions of the Presidency. 19-20 June 2000. URL: http://www. europarl.europa.eu/summits/fei1_en.htm (consulted on: 18.05.2019).

6. Declaration of the EU-Western Balkans Summit in Thessaloniki. 21 June 2003. C/03/163. URL: https://europa. eu/rapid/press-release_PRES-03-163_en.htm (consulted on: 18.05.2019).

7. European Commission. European Neighbourhood Policy and Enlargement Negotiations. Accession criteria. URL: https://ec.europa.eu/neighbourhood-enlargement/policy/glossary/terms/accession-criteria_en (consulted on: 07.10.2018).

8. European Commission. European Neighbourhood Policy and Enlargement Negotiations. Chapters of the acquis. URL: https://ec.europa.eu/neighbourhood-enlargement/policy/conditions-membership/chapters-of-theacquis_en (consulted on: 07.10.2018).

9. European Council. Sofia declaration of the EU-Western Balkans summit. 17 May 2018. URL: https://www.consilium.europa.eu/media/34776/sofia-declaration_en.pdf (consulted on: 15.10.2018).

10. European Commission. 2019 Communication on EU Enlargement Policy. COM(2019) 260 final. URL: https:// ec.europa.eu/neighbourhood-enlargement/sites/near/files/20190529-communication-on-eu-enlargement-policy.pdf (consulted on: 07.10.2018).

11. European Commission. Commission Staff Working Documents. URL: https://ec.europa.eu/neighbourhoodenlargement/news_corner/key-documents_en?f\%5B0\%5D=field_document_repository_filter\%3A319 (consulted on: 20.06.2019):

A. Montenegro:

a. Montenegro 2012 Progress Report. SWD(2012) 331 final;

b. Montenegro 2013 Progress Report. SWD(2013) 411 final;

c. Montenegro 2014 Progress Report. SWD(2014) 301 final;

d. Montenegro 2015 Report. SWD(2015) 210 final;

e. Montenegro 2016 Report. SWD(2016) 360 final;

f. Montenegro 2018 Report. SWD(2018) 150 final;

g. Montenegro 2019 Report. SWD(2019) 217 final.

B. Serbia:

a. Serbia 2012 Progress Report. SWD(2012) 333 final;

b. Serbia 2013 Progress Report. SWD(2013) 412 final;

c. Serbia 2014 Progress Report. SWD(2014) 302 final;

d. Serbia 2015 Report. SWD(2015) 211 final;

e. Serbia 2016 Report. SWD(2016) 361 final;

f. Serbia 2018 Report. SWD(2018) 152 final;

g. Serbia 2019 Report. SWD(2019) 219 final.

C. North Macedonia:

a. The former Yugoslav Republic of Macedonia 2012 Progress Report. SWD(2012) 332 final;

b. The former Yugoslav Republic of Macedonia 2013 Progress Report. SWD(2013) 413 final;

c. The former Yugoslav Republic of Macedonia 2014 Progress Report. SWD(2014) 303 final;

d. The former Yugoslav Republic of Macedonia 2015 Report. SWD(2015) 212 final;

e. The former Yugoslav Republic of Macedonia 2016 Report. SWD(2016) 362 final;

f. The former Yugoslav Republic of Macedonia 2018 Report. SWD(2018) 154 final;

g. North Macedonia 2019 Report. SWD(2019) 218 final.

D. Albania:

a. Albania 2012 Progress Report. SWD(2012) 334 final;

b. Albania 2013 Progress Report. SWD(2013) 414 final;

c. Albania 2014 Progress Report. SWD(2014) 304 final;

d. Albania 2015 Report. SWD(2015) 213 final;

e. Albania 2016 Report. SWD(2016) 364 final;

f. Albania 2018 Report. SWD(2018) 151 final;

g. Albania 2019 Report. SWD(2019) 215 final.

E. Bosnia and Herzegovina:

a. Bosnia and Herzegovina 2012 Progress Report. SWD(2012) 335 final; 

b. Bosnia and Herzegovina 2013 Progress Report. SWD(2013) 415 final;
c. Bosnia and Herzegovina 2014 Progress Report. SWD(2014) 305 final;
d. Bosnia and Herzegovina 2015 Report. SWD(2015) 214 final;
e. Bosnia and Herzegovina 2016 Report. SWD(2016) 365 final;
f. Bosnia and Herzegovina 2018 Report. SWD(2018) 155 final;
g. Analytical Report. SWD(2019) 222 final.

12. Interview with an EU official in charge of the Western Balkans. 11 April 2019.

13. United Nations. General Assembly Resolutions A/RES/68/262, A/RES/71/205, A/RES/72/190, A/RES/73/263, A/RES/73/194. URL: https://www.un.org/en/sections/documents/general-assembly-resolutions/ (consulted on: 15.06.2019).

14. United Nations. General Assembly Voting Records on Resolutions Resolutions A/RES/68/262, A/RES/71/205, A/RES/72/190, A/RES/73/263, A/RES/73/194. URL: https://www.un.org/en/ga/documents/voting.asp (consulted on: 15.06.2019).

15. Council of the European Union. Stabilisation and Association Agreement between the European Union and Kosovo*. URL: http://data.consilium.europa.eu/doc/document/ST-10728-2015-REV-1/en/pdf (consulted on: 18.06.2019).

16. Frank Schimmelfennig and Ulrich Sedelmeier. The Europeanization of Eastern Europe: the External Incentives Model Revisited. Paper for the JMF @25 Alumni Conference. European University Institute. 22/23 June 2017.

17. The Observatory of Economic Complexity. Montenegro, Serbia. URL: https://oec.world/en/ (consulted on: 17.06.2019).

18. Government of Montenegro. Prime Minister Đukanović - Montenegro follows its Euro-Atlantic agenda without conducting anti-Russian policy. 25 April 2014. URL: http://www.gov.me/en/search/138114/Prime-Ministerdukanovic-Montenegro-follows-its-Euro-Atlantic-agenda-without-conducting-anti-Russian-policy.html (consulted on: 17.06.2019).

19. Ministry of Foreign Affairs of the Republic of Serbia. Without the support of Russia, no solution can be reached between Belgrade and Pristina. 21 August 2018. URL: http://www.mfa.gov.rs/en/press-service/statements/18072 (consulted on: 17.06.2019).

20. Interview with a Serbian incumbent diplomat. 10 April 2019. 